\title{
Идентификация коллекционных образцов рода Spiraea L. (Rosaceae) Ботанического сада Института биологии Коми НЦ УрО РАН по молекулярным данным
}

\section{Identification of collection samples of the genus Spiraea L. (Rosaceae) of the Botanical garden of the Institute of Biology of Komi SC UrB RAS according molecular data}

\author{
Смирнова А. Н., Зайнуллина К. С. \\ Smirnova A. N., Zainullina K. S. \\ Институт биологии Коми НЦ УрО РАН, г. Сыктывкар, Россия. E-mail: smirnova@ib.komisc.ru \\ Institute of Biology of Komi SC UrB RAS, Syktyvkar, Russia
}

\begin{abstract}
Peфepam. Род Spiraea L. подсемейства Spiraeoideae семейства Rosaceae таксономически сложен. Нами проведены молекулярно-генетические исследования с целью идентификации видов и таксонов подвидового ранга родового комплекса Spiraea. По результатам работы получены последовательности участка ITS рибосомальной ДНК 21 образца Spiraea, включая один природный образец местного вида Spiraea media Franz Schmidt, у части видов ITS фрагмент секвенирован впервые.
\end{abstract}

Ключевые слова. Ботанический сад, идентификация, ITS-регион, нуклеотидная последовательность, рДНК, Spiraea, таксономия.

Summary. The genus Spiraea L. of the subfamily Spiraeoideae of the Rosaceae family is taxonomically complex. We conducted molecular genetic studies to identify taxa of the genus. The ITS sequences of ribosomal DNA of 21 Spiraea samples including one wild sample of the local species of Spiraea media are obtained. Some of these ITS fragments were first sequenced.

Key words. Botanical garden, identification, ITS-region, nucleotide sequence, rDNA, Spiraea, taxonomy.

\section{Введение}

Для видовой идентификации и выявления гибридов растений необходимы исследования на стыке ботаники и генетики. Для того чтобы в полной мере изучить биологические особенности видов при интродукции, необходимо точно установить их таксономическую принадлежность. Нами проведены молекулярно-генетические исследования с целью идентификации видов и таксонов подвидового ранга рода Spiraea L.

Род Spiraea (спирея) подсемейства Spiraeoideae семейства Rosaceae таксономически сложен. Объем рода Spiraea до сих пор точно не установлен, т. к. имеется много сведений о межвидовых гибридах; разные авторы включают в него от 90 (Шульгина, 1954) до 100 (Бонюк, 2008) видов.

Известно, что спиреи при совместном произрастании, особенно в условиях культуры, способны давать гибриды (Мамаев, Семкина, 1988), что не гарантирует видовую чистоту растений, полученных из семян при перекрестном опылении. Идентификация видов рода Spiraea на основании только морфологических признаков затруднена и на сегодняшний день остается актуальным вопросом.

В течение последнего десятилетия активно ведется изучение систематики, генетической изменчивости и филогении рода Spiraea с привлечением разных молекулярных маркеров, в т. ч. ядерных (Zhang et al., 2006; Potter et al., 2007; Huh et al., 2008; Huh, 2012; Полякова и др., 2015). В настоящее время одними из наиболее популярных последовательностей для филогенетических исследований рас- 
тений являются последовательности внутренних транскрибируемых спейсеров рибосомальных генов (ITS - internal transcribed spacer). Цель исследования - идентификация коллекционных образцов рода Spiraea по молекулярно-генетическим данным. Задачи включали определение последовательности участка ITS (ITS1-5.8S-ITS2) рибосомальной ДНК у представленных коллекционных образцов Spiraea и верификацию таксономического статуса образцов спиреи по маркерным последовательностям ITS-фрагмента ДНК.

\section{Материалы и методы}

Объекты исследований - образцы видов и гибридов Spiraea коллекции Ботанического сада Института биологии Коми НЦ УрО РАН, материал для исследования - высушенные листья спиреи.

Общая ДНК была извлечена из высушенных измельченных образцов растений с помощью набора для извлечения ДНК из растительного материала "DNeasy Plant Mini Kit" (Qiagen, Hilden, Германия). Для амплификации фрагмента ITS1-5.8 S-ITS2 использовали праймеры ITS-5 5'GGAAGTAAAAGTCGTAACAAGG-3' и ITS-4 5'-TCCTCCGCTTATTGATATGC-3'. Амплификация проводилась в термоциклере T100 (BioRad Laboratories, Inc, США) по схеме: предварительная денатурация 5 мин при $95^{\circ} \mathrm{C} ; 30$ циклов: денатурация 30 сек при $94{ }^{\circ} \mathrm{C}$, отжиг 30 сек при $57{ }^{\circ} \mathrm{C}$, элонгация 40 сек при $72{ }^{\circ} \mathrm{C}$; и финальная элонгация 2 мин при $72{ }^{\circ} \mathrm{C}$. Продукты амплификации отделяли электрофорезом в 1,3 \% агарозном геле. Для очистки полученного продукта использовался набор Qiaquick Gel Extraction Kit (Qiagen, Германия). Количество выделенной ДНК и ПЦР-продукта определяли с помощью флуориметра Qubit 1.0 (Invitrogen/Life Technologies, США).

Результаты секвенирования были обработаны и проанализированы в программном обеспечении MEGA 7. Поиск гомологичных нуклеотидных последовательностей генов рДНК осуществлялся с помощью программы BLAST в базе данных NCBI GenBank (htpp:/www.ncbi.nlm.nih.gov).

По результатам работы получены последовательности участка ITS рибосомальной ДНК 21 образца Spiraea, включая один природный образец местного вида Spiraea media, для части из них ITS фрагмент расшифрован впервые. В полученных последовательностях рибосомальной ДНК образцов спиреи общая длина ITS-участков варьировала от 622 до 752 п. н.

В анализе с помощью программы BLAST не выявлено 100\%-ной идентичности последовательностей ITS исследуемых образцов спирей с образцами в GenBank. Степень идентичности определяли как долю (в процентах) одинаковых нуклеотидов, занимающих одни и те же позиции у каждой из сравниваемых нуклеотидных последовательностей (максимальная степень идентичности в сумме представлена итоговым баллом и процентом идентификации). За наиболее высокую степень идентичности принимали 99\%-ный уровень.

\section{Заключение}

При сравнении последовательностей ITS рибосомной ДНК, выделенной из коллекционных образцов Spiraea, с данными NCBI GenBank установлено, что все исследуемые образцы относятся к видам Spiraea семейства Rosaceae. Наивысшая степень идентичности полученных последовательностей соответствует 99\%-ному уровню последовательностей нуклеотидов из GenBank.

Образец Spiraea media, взятый нами для сравнения из природной популяции флоры Республики Коми, оказался высокоидентичным (99\%) как образцам данного вида в коллекции Ботанического сада (БС), так и образцам в базе данных GenBank.

Образцы подвидового ранга - формы и разновидности - оказались родственными образцам конкретного вида, с чуть меньшим процентом совпадения последовательностей (S. media f. mollis C. K. Schneid). Для гибридов максимальное совпадение последовательностей закономерно оказалось от одной или обоих исходных родительских видов (Spiraea $\times$ bumalda Burv., $S . \times$ vanhouttei (Briot.) Zabel).

Образец Spiraea miyabei Koidz. на 99 \% идентифицируется как очень близкий по морфологии и филогении вид Spiraea rosthornii Pritz., Spiraea flexuosa Fisch. - как Spiraea media. С учетом вновь полученных данных эти образцы в коллекции БС, возможно, следует переопределить.

Выявленная нами степень нуклеотидного полиморфизма ITS-региона демонстрирует приемлемую пригодность для идентификации видов и меньшую - для обнаружения межвидовых гибридов рода 
Spiraea. Предварительные результаты анализа показывают, что в целом молекулярные и биоморфологические данные согласуются между собой.

Таким образом, применение молекулярно-генетических методов с целью идентификации видов в условиях культивирования следует применять в сочетании с традиционными методами определения растений по определителям и гербарным образцам. Полученные результаты по рибосомальным ITS- последовательностям могут служить дополнительным материалом при изучении филогении рода Spiraea L. Полученные ITS последовательности спирей частично депонированы в международном банке генетических данных NCBI GenBank под номерами MK530326, MK570224, MK570226, MK570285, MK570293, MK570298, MK570301, MK570302, MK570303, МК570453 и МК570455.

\section{Благодарности}

Выражаем огромную благодарность сотрудникам ЦКП «Молекулярная биология» Института биологии Коми НЦ УрО РАН - Шадрину Д. М. и Пылиной Я. И. за выделение и секвенирование ДНК.

Исследования выполнены в рамках государственного задания по теме «Закономерности процессов репродукции ресурсных растений в культуре на европейском Северо-Востоке" (№ AAАA-A17117122090004-9) на базе УНУ «Научная коллекция живых растений» Ботанического сада Института биологии Коми НЦ УрО РАН, регистрационный № 507428. Гербарные образцы хранятся в УНУ «Научный гербарий SYKO Института биологии Коми НЦ УрО РАН».

\section{ЛИТЕРАТУРА}

Бонюк 3. Г. Таволги (Spiraea L.). - Киев: ВПЦ Киівский університет, 2008. - 248 с.

Мамаев C. A., Семкина Л. $\boldsymbol{A}$. Интродуцированные деревья и кустарники Урала (розоцветные). - Свердловск: AH CCCP, УO, 1988. $-105 \mathrm{c}$.

Полякова Т. А., Шатохина А.В., Ширманов М.В., Бондаренко Г.Н. Оценка таксономических отношений у сибирских представителей секции Chamaedryon Ser. рода Spiraea L. (Rosaceae Juss.) на основе анализа нуклеотидного полиморфизма ITS-региона // Проблемы ботаники Южной Сибири и Монголии : сб. науч. ст. по материалам Четырнадцатой междунар. науч.-практ. конф. (Барнаул, 25-29 мая 2015 г.). - Барнаул: Изд-во АлтГУ, 2015. - C. 353-358.

Шульгина В. В. Род Таволга - Spiraea L. // Деревья и кустарники СCCP. - Т. 3. - М.-Л., 1954. - С. 286-332.

$\boldsymbol{B L A S T}$ : Basic local alignment search tool, 2018 URL: https://blast.ncbi.nlm.nih.gov/Blast.cgi (Дата обращения 02.12.2018)

GenBank Home, 2018. URL: http://www.ncbi.nlm.nih.gov/genbank/. (Дата обращения 14.01.2019)

Huh M. K., Huh H. W., Lee S. Y. A taxonomic study of the genus Spiraea in Korea using sequences of ITS // Journal of Life Science, 2008. - Vol. 18. - № 5. - P. 694-700.

Huh M. K. Analysis of the phylogenetic relationships in the genus Spiraea based on the nuclear ribosomal DNA ITS region // Journal of Life Science, 2012. - № 22. - P. 285-292.

Potter D., Still S. M., Grebenc T., Ballian D., Bozic G., Franjiae J., Kraigher H. Phylogenetic relationships in tribe Spiraeae (Rosaceae) inferred from nucleotide sequence data // Plant Syst. Evol., 2007. - № 266 (1-2). - P. 105-118.

Zhang Z., Fan L., Yang J., Hao X., Gu Z. Alkaloid polymorphism and ITS sequence variation in the Spiraea japonica complex (Rosaceae) in China: traces of the biological effects of the Himalaya-Tibet Plateau uplift. // Am. J. Bot., 2006. - № 93 (5). - P. 762-769. 